Boise State University

ScholarWorks

Anthropology Faculty Publications and

Presentations

Department of Anthropology

$1-1-2011$

\title{
Alluvial Stratigraphy and Geoarchaeology in the Big Fork River Valley, Minnesota: Human Response to Late Holocene Environmental Change
}

\author{
Christopher Hill \\ Boise State University \\ George (Rip) Rapp \\ University of Minnesota Duluth \\ Zhichun Jing \\ University of British Colombia
}




\title{
Alluvial Stratigraphy and Geoarchaeology in the Big Fork River Valley, Minnesota: Human Response to Late Holocene Environmental Change
}

\author{
Christopher L. Hill \\ Boise State University \\ George (Rip) Rapp \\ University of Minnesota Duluth \\ Zhichun Jing \\ University of British Colombia
}

\begin{abstract}
The Late Quaternary geomorphology and stratigraphy of the Big Fork River valley, within the Rainy River basin of northern Minnesota, reveals evidence of prehistoric human interaction with late Holocene riverine environments. By $11000{ }^{14}$ C B.P., deglaciation made the region inhabitable by human groups using Clovis artifacts. Human habitation would also have been possible during the Moorhead low water stage of glacial Lake Agassiz, starting at $10500{ }^{14} \mathrm{C}$ B.P. Near its confluence with the Rainy River, the valley floor of the Big Fork valley consists of a floodplain complex and two terraces. The multi-component stratified Hannaford site is situated within the active floodplain. Overbank deposits contain artifacts in primary context, while artifacts within the point bar deposits are in secondary archaeological context; these deposits are associated with changing alluvial settings as the river moved eastward. Aggradation of the valley fill beneath the lowest surface (T0, floodplain complex) began by 3000 years ago and is associated with human activities focused on seasonal fishing and the use of riparian resources from 1300 to $650{ }^{14} \mathrm{C}$ B.P.
\end{abstract}

\section{Introduction}

Human/environmental interactions include the role landscape contexts and resources play in determining where human activities take place, and the ways humans respond to changing environmental situations. Quaternary fluvial landforms and stratigraphic sequences provide information on the long term consequences of environmental change (Benito et al. 1998; Gregory \& Benito 2003). While landform evolution often is the result of Late Quaternary natural climatic variability it can also result from shifts in biomes, base levels, or other factors that influence how humans adapt to environmental conditions and how the archaeological record is subsequently modified (Bull 1991; Knox 1983; Knox 1993; Schumm \& Brakenridge 1987). For instance, in some formerly glaciated areas, floodplains can be relatively low energy systems that have been subjected over the last 10000-8000 years to slow lateral migration and overbank sedimentation. Environmental change also has been implicated in the formation of terrace sequences as a result of down-cutting during and after the Pleistocene/Holocene transition. On some scales, river valleys become entrenched and aggradational terraces are the result of the combined of surface uplift and fluctuating climate (Brigland \& Westaway 2008). For example, climate conditions leading to reduced hydrologic base levels along with isostatic rebound can facilitate retrenchment within a river valley.

This study documents the Late Quaternary geomorphic evolution of a river valley in a deglaciated area of central North America, evaluates the role of alluvial processes for interpreting the prehistoric archaeological record, and uses this information to examine how humans have been influenced by and responded to environmental change, with an emphasis on the late Holocene. Although changes in the regional environment (site macroenvironment, Butzer 1982) are examined, mesoenvironmental (topographic setting and landforms) and microenvironmental (site strata and local environmental elements) landscape contexts are emphasized. The focus is on the lower drainage of the Big Fork River in northern Minnesota, along the U.S.-Canada border within the Rainy River basin, where the valley fills contain a post-glacial environmental record that can be directly related to archaeological assemblages reflecting prehistoric human activities. 


\section{Regional setting}

The Big Fork River is a meandering stream that originates in north-central Minnesota (Fig. 1) and flows northward for about $266 \mathrm{~km}$ before it enters Rainy River. The study area is in the lower reach of the Big Fork River at its junction with the Rainy River, about $27 \mathrm{~km}$ west of Fort Francis/International Falls. Near the confluence with the Rainy River, the channel is about 100-200 m wide and the valley, as marked by the $335 \mathrm{~m}(1100 \mathrm{ft})$ contour, is about $1 \mathrm{~km}$ wide. In this vicinity there are several important archaeological localities including the Smith Mound complex adjacent to the Rainy River and east of the Big Fork, and the Hannaford site situated immediately west of the Big Fork (Fig. 2). Artifacts from these sites are local variants of assemblages taxonomically assigned to the Late Woodland Complex (Lenius and Olinyk 1990). At the Smith site, Late Woodland assemblages have been classified into several groups chiefly distinguished and subdivided on the basis of ceramic typology. Radiocarbon dates and stratigraphic contexts suggest that Smith site Laurel artifacts date from about 1500 to $1250{ }^{14} \mathrm{C}$ B.P. while Early Blackduck pottery dates to around $1000{ }^{14} \mathrm{C}$ B.P. (Lugenbeal 1978). Assemblages containing Late Blackduck ceramics are assigned to the Rainy River Composite or Rainy River Late Woodland Complex and date from about 900 to $650{ }^{14}$ C B.P. (Lugenbeal 1978, Lenius and Olinyk 1990, Arizigian 2008).

Before the development of the Big Fork River, this region of northern Minnesota and northwestern Ontario was covered by late Wisconsin glacial ice. Final deglaciation occurred around $11000{ }^{14} \mathrm{C}$ B.P. when the ice margin was in the vicinity of the Rainy River moraine, north of the Big Fork. The area was exposed during the Moorhead low water stage of glacial Lake Agassiz and then reflooded until about $9500{ }^{14} \mathrm{C}$ B.P. Since then the geomorphology and stratigraphy of the area has been controlled by the fluvial regimes of the Rainy and Big Fork rivers.

\section{Materials and Methods}

The data for this study consist of published and unpublished proposals and reports, field notes, photographic slides and excavation forms, maps and profiles, air photographs, U.S.G.S. topographic maps, sediment cores, and laboratory analyses of sediments (Hill et al. 1995; Rapp et al. 1995). We first examined published maps and reports, and interpreted aerial photographs, satellite images, and 1:24000 topographic maps. These provided an understanding of the basic landforms and were used to place the lower Big Fork drainage within the context of the regional deglaciation and glacial Lake Agassiz chronologic framework. Field studies allowed construction of a geomorphic map, which defined and characterized the floodplain and terraces along the river, and the creation of a generalized cross-section across the valley. The maps and cross-sections illustrated the relation of the recorded archaeological occurrences with landform sediment assemblages in the lower Big Fork drainage.

The sedimentary sequences beneath the floodplain complex provided information on the stratigraphic relationships between artifact assemblages and the role natural processes had in patterning the archaeological record. The main study area is located on the west bank of the Big Fork River, approximately $1 \mathrm{~km}$ south of the confluence with the Rainy River (Fig. 2). A topographic map with $10 \mathrm{~cm}$ contour intervals was created for the lower terrace in the vicinity of the Hannaford archaeological site. Archaeological excavations reached depths of $2 \mathrm{~m}$ below the surface. Stratigraphic profiles from these excavations were used in conjunction with the detailed analysis of 19 cores. Fifteen cores reached a maximum depth of $3.1 \mathrm{~m}$ (1-92, 1A-92, 1B-92, 1C-92, 2-92, 2a-92, 3-92 through 11-92). An additional three cores (1-94, 2-94, and 3-94) were made available by the Minnesota Department of Transportation, and a core was drilled from an oxbow lake on the east side of the river. The stratigraphic profiles and sediment cores of Big Fork alluvial deposits were used to interpret the record of past river activity associated with the formation of the floodplain and the geoarchaeological context of Late Woodland (late Holocene) artifactual occurrences.

Stratigraphic exposures (archaeological sections) and cores were described in the field and selected sediment samples from the cores and sections were analyzed for grain-size distribution and loss-on-ignition to determine percent organic matter and percent carbonate. To place the landforms and archaeological materials in chronologic context, 33 samples were submitted to Beta Analytic, Inc., for Accelerator Mass Spectrometry (AMS) radiocarbon dating. Ten samples are from the cores, 22 from the excavation units, and one is from the oxbow lake on the east side of the river (Table 1). All dates are reported as years ${ }^{14} \mathrm{C}$ B.P. 


\begin{abstract}
Results
Results of this study document the presence of three geomorphic surfaces in the lower Big Fork River Valley. The relationship of these surfaces is depicted in Figs. 2 and 3. The oldest and highest of these surfaces (T2) is approximately $335 \mathrm{~m}$ above sea level (masl). Test borings on the upper terrace on the east side of the Big Fork River revealed alluvial deposits overlying glacial lake deposits including approximately $1.8 \mathrm{~m}$ of silt clay and varved clay (Birk \& George 1976). The lowest surface (T0) is the present day floodplain; it consists of a complex of surfaces ranging in elevation from 329 to 331 masl. A scarp separates the floodplain from the $335 \mathrm{~m}$ surface (T2) on the east side of the Big Fork. At the Hannaford and Smith Mound sites, the floodplain is underlain by strata that contain artifacts. On the east side of the Big Fork River there are several floodplain surfaces. For instance, the Smith site earthen mounds are on the $329 \mathrm{~m}$ surface. Also, there are distinct meander scars on the T0 surface delineating the locations of abandoned channels (Fig. 2).

On the west side of the river, the Hannaford site lies at an elevation of approximately 331 masl. Local swales are clearly visible on air photographs and satellite images. This topography continues from the edge of the Big Fork River westward for about $487 \mathrm{~m}$ with a general northwest trend. Directly to the south-southwest of the Hannaford site is another set of ridges and swales that have a changing alignment, starting from a trend toward the northeast, then north and finally curving toward the northeast around the Hannaford site. The ridge-and-swale topography is the geomorphic expression of an eastward lateral movement of the Big Fork River. To the west, a scarp separates the floodplain complex (T0) ridge-and swale-topography from the lowest terrace (T1, starting at approximately 332 masl). The T1 contains clearly visible meander scars. The youngest channel of the middle terrace is marked by contours at an elevation of 332.23 masl. Meander scars indicate that a former channel cut laterally into the fill of a higher terrace (T2). The T2 surface has an elevation of approximately 335 masl. The meander scar pattern west of the Hannaford site on the lower terrace (T1) is clearly older than the ridge and swale topography on the floodplain at the Hannaford site. The meander channels seem to have been cut by a river moving westward.
\end{abstract}

Detailed studies of the strata which comprise the valley fill provide a basis for evaluating the alluvial processes active in forming the present floodplain. Based on the archaeological stratigraphic profiles and drill cores, we have developed a model of late Holocene river behavior for the floodplain complex (T0). As a river channel shifts laterally, alluvium aggrades in a floodplain creating bottom stratum or lateral accretion deposits. Top stratum or vertical accretion deposits aggrade when discharge inundates the plain. Lateral accretion deposition is within and adjacent to the channel while vertical accretion sediments aggrade beyond the channel. Our model takes into consideration the variation in lithofacies to evaluate both synchronic and diachronic patterns of depositional environments. This is based on the concept that alluvium aggrades at different locations within a floodplain creating alluvial facies that can signify variability of depositional environments at a particular time or, for a stratigraphic sequence, changes that take place over time.

The sedimentary architecture consists of "bottom series" coarse-grained sediments and "top series" fine-grained sediments. The "bottom series" is dominated by sediments formed by the process of lateral movement of the channel (such as point bar and channel bed deposits) under normal river conditions. The "top series" is composed primarily of fine-grained sediments formed only during the bank-full stage (higher than normal stage) and is exposed above the water level during most of the time, particularly those sediments on or near channel banks.

The Hannaford site is divided into five excavation areas, A through E (Fig. 4). Area A is situated on the west side of the Hannaford site where stratum 1 is interpreted as a point bar deposit, the product of lateral accretion of the Big Fork River (Fig. 5). It is topographically represented by a subsurface ridge-and-swale stretching northwest-southeast across the excavated area. The sedimentary deposits in the swale became parallel to the modern surface with increasing height, indicative of the gradual filling of overbank flooding sediments after the formation of stratum 1. Strata 2 through 7 in Fig. 5 are primarily the result of suspended-load deposition on the ridge-and-swale topography of the preexisting point bar. This inference is based on several lines of evidence, including the relatively fine-grained sediments above stratum 1. Thus, strata 2 through 7 can be interpreted as a "top series" in contrast to stratum 1 , which appears indicative of lateral accretion and is thus designated as a "bottom series". The "top series" strata contain Early and Middle Blackduck artifacts and also fish remains (consisting solely of lake sturgeon, Acipenser fulvescens). Fish remains dominate the faunal assemblage. Another indication of a subsistence focus on riparian resources is the presence of beaver, muskrat, and river otter remains in contrast to very rare occurrences of deer, elk, and moose. The high number of harpoons in the Area A assemblage supports the contention that spearing sturgeon 
was a major activity. Table 1 presents a summary of stratigraphic contexts associated with the radiocarbon samples. According to the available radiocarbon dates and diagnostic artifacts, the "bottom series" deposits at Area A might have formed before ca. $1400{ }^{14}$ C B.P. (Fig. 5).

The depositional sequence in Area B (Fig. 4) shows a similar pattern to that seen in Area A, consisting of both "top series" and "bottom series" sediments. The "top series" is comprised of the top $60 \mathrm{~cm}$ of sediments formed by suspended-load deposition. Below the "top series" are layers of relatively coarse-grained sediments including laminated fine to medium and sandy silt. These constitute the "bottom series" and are a product of lateral accretion. Two radiocarbon dates from Area B indicate "top series" sediments were deposited starting around $1300{ }^{14} \mathrm{C}$ B.P. (Table 1). Early and Middle Blackduck artifacts were recovered from the "top series" and fish dominate the faunal assemblage.

Area C is situated on the top of the modern river levees on the east of the site (Fig. 4) where the "top series" might have started forming about 900 B.P. or later (Table 1). Area D is also situated on the eastern side of the site (Fig. 4) where it is topographically about $30 \mathrm{~cm}$ higher than Areas A and B due to its levee setting. Twenty-three strata were recorded (Fig. 6). Ages of 1020 and $1150{ }^{14}$ C B.P. (Table 1) from the "bottom series" could be from material in secondary context. Eight radiocarbon dates are assigned to the "top series" in Area D (Table 1). Three dates ranging from 1160 to $1020{ }^{14}$ C B.P. are associated with Middle Blackduck artifacts found in an organic-rich zone. A very thin bed of sand (stratum 15) contains no artifacts and probably represents an individual flood. The organic-rich zone is overlain by the silt of stratum 17. Stratum 18 is composed of a series of discontinuous lenses of sand and contains no artifacts and represents another large flooding event. Late Blackduck artifacts were recovered from strata 19 through 23. Stratum 20 dates to about $700{ }^{14}$ C B.P. (Table 1). Thus the "top series" might have started forming after about $900{ }^{14} \mathrm{C}$ B.P. in the vicinity of Area D where fish, especially redhorse suckers (Moxostoma macrolepidotum), dominate the faunal assemblage, indicating spring fishing was a major activity. The riparian setting is also reflected by the presence of beaver, porcupine, muskrat, and river otter.

The locations of the cores in relation to the archaeological units are shown on Fig. 4. Stratigraphic information from the cores is more detailed than the data available from the archaeological excavations, so it is the primary basis for our geomorphic interpretations. Core 9-92, about $5 \mathrm{~m}$ west of Area A, has a "top series" subdivided into several layers (Fig. 7). The "bottom series" consists mainly of fine to medium sands interbedded with silt and clayey silts dating to $2130{ }^{14} \mathrm{C}$ B.P. (Table 1). Cross-bedding structure and a fining-upward sequence are present in the lower part of the coarse-grained deposits.

Core 11-92, about $4 \mathrm{~m}$ southeast of Area B (Figs. 7 and 8), has a "bottom series" with dates of 1750 and $1340{ }^{14} \mathrm{C}$ B.P. (Table 1). The lower $1.2 \mathrm{~m}$ of the sequence is composed of fine to medium cross-bedded sand with several thin layers of silt and clayey silt. Overlying the "bottom series" of coarse-grained deposits is $10 \mathrm{~cm}$ of clay with three 1-2 $\mathrm{cm}$ thick dark lenses which may be organic-rich flood drapes (Mandel and Bettis 2001). On the top of this stratum is a $20 \mathrm{~cm}$ silty clay or clayey silt with blocky structure typical of pedogenically-unmodified, organic-rich flood drapes with high clay content. Radiocarbon dates from both Core 11-92 and the excavation units suggest that the development of the "top series" started around $1300{ }^{14}$ C B.P. in Area B (Table 1), about 100 years later than Area A.

Core 1-94 was drilled northwest of Area D (Fig. 4). A layer of dark gray silt and clayey silt with some plant remains represents the "top series" deposits. Underlying the silt and clayey silt are the relatively coarse-grained sediments of the "bottom series." These are gravelly sand and sandy gravel separated by $30 \mathrm{~cm}$ of massive silty clay with many wood and root remains interpreted as a slackwater facies that accumulated around $1470{ }^{14}$ C B.P (Table 1).

Core 2-94 is situated on a $0.5 \mathrm{~m}$-high ridge southwest of the archaeological excavations, $43.5 \mathrm{~m}$ from the excavation datum (Fig. 2). It has the same sedimentary architecture as seen within the site, including both "top series" and "bottom series" (Fig. 8). The lowest sediments are coarse sand and gravelly sand. They grade upward into fine to medium sand interbedded with thin beds of silty or sandy clay and silt showing cross-bedding structure and a finingupward sequence. The gravelly sand and sand layers constitute the "bottom series". Four radiocarbon ages were determined on charcoal from the "bottom series" in Core 2-94. A charcoal sample dated to $5400{ }^{14} \mathrm{C}$ B.P. may have been redeposited; the date appears unreasonably old in terms of the stratigraphic context. Three other dates range from 2980 to $2140{ }^{14} \mathrm{C}$ B.P (Table 1). Above the "bottom series" is $10 \mathrm{~cm}$ of dark grayish brown clayey silt containing few very thin organic lenses that grades upward to silty clay. The top $35 \mathrm{~cm}$ is an A horizon consisting of 
an organic clay with moderate blocky structure and many plant remains. The "top series" of relatively fine-grained deposits and associated soils can be correlated with the stratigraphic sequence within the Hannaford site.

Core 3-92 is in a swale about $10.5 \mathrm{~m}$ west of Core 2-94 (Fig. 8) and contains a relatively thin "top series" composed of clays dated to $1290{ }^{14}$ C B.P. (Table 1). The "bottom series" consists of medium sand interlayered with very thin beds of silty clay that grades downward into cross-bedded coarse sand. Wood in Core 5-92 dated to $1360{ }^{14} \mathrm{C}$ B.P. (Fig. 7 and Table 1) was recovered from a $40 \mathrm{~cm}$ thick deposit overlain by medium sand that grades upward into fine sand and silt. The fine sand and silt could have been deposited on a floodplain by vertical accretion during a moderate or high magnitude flood event. Thus, we interpret the layer containing wood remains as a slackwater facies prior to $1300{ }^{14} \mathrm{C}$ B.P.

Figures 7 and 8 are cross-sections based on the cores studied on the lower terrace (T1). In general, the depths of the organic-rich layers gradually increase eastward toward the present location of the river. The formation of the organic-rich strata can be attributed to inundation proximal to the channel with little if any contribution resulting from incipient pedogenesis or prehistoric human activity. After being deposited on the floodplain, the surface of the organic-rich layers would have been available for human activities. The sediments below the organic-rich deposits are composed mainly of fine to coarse sand interlayered with clay and are interpreted as the "bottom series." The deposits above the organic-rich layers are always silty clay and silt; these fine-grained sediments are assigned to the "top series." The same bipartite sedimentary architecture occurs in the off-site Cores 2-94 and 3-94 and can be correlated to the archaeological excavations and on-site cores (Fig. 8).

Based on the sedimentary sequence and stratigraphic correlation shown in excavation units and drill cores the sedimentary stratigraphy of the floodplain complex consists of two major facies, "bottom series" and "top series." The "bottom series" was created primarily by the process of lateral channel movement of the Big Fork River. It is composed of relatively coarse-grained sediments, including gravelly sand and coarse to fine sand with thin beds of silt and silty clay, showing a fining-upward sequence. The sediments are topographically expressed as a point bar.

The "top series" deposits consist of relatively fine-grained sediments, mostly silty clay and clay, deposited by overbank flooding. Deposition of these overbank sediments led to vertical accretion at the site. Artifacts and features in primary contexts are restricted stratigraphically to the "top series." As the fine-grained sediments slowly accumulated on the point bar, humans were present on the floodplain and left a stratified archaeological record in the "top series." The "top series" deposits become thicker toward the channel of the Big Fork River because a natural levee was built up immediately adjacent to the channel. Due to the decreasing age of the underlying "bottom series" from southwest to northeast, the "top series" sediments show not only a decrease in age from bottom to top (vertically) but also in age from southwest to northeast (horizontally).

\section{Discussion}

The Rainy River region of northwestern Ontario and northern Minnesota was affected by two late Wisconsin age glacial advances: the Rainy lobe from the northeast and the St. Louis sublobe of the Red River-Koochiching lobe from the northwest (Hill 2007). The Rainy lobe retreated to the northeast forming a succession of moraines including the Vermilion, Rainy River, and Eagle-Finlayson moraines. The area between the Vermilion moraine to the south, and the Eagle-Finlayson and Brule Creek moraines to the north was deglaciated before $10400{ }^{14} \mathrm{C}$ B.P. (Lowell et al. 2009). Following the retreat of the Rainy lobe, the St. Louis sublobe of the Red River-Koochiching lobe expanded to the southeast. The glacial margin was located in the vicinity of the Rainy River moraine immediately north of the Big Fork area approximately $11000{ }^{14}$ C B.P. (Bajc 1991), which generally corresponds to the time Clovis artifacts occur throughout North America. Melting of the St. Louis sublobe led to the formation of glacial Lake Agassiz.

Lake Agassiz initially formed around $12000{ }^{14} \mathrm{C}$ B.P. and had a low water stage (Moorhead phase) from about 10500 to $9300{ }^{14}$ C B.P. (Bajc et al. 2000; Fisher et al. 2008) when the lower Big Fork area was exposed to subaerial conditions. Human populations using Folsom artifacts are generally dated to about $10500{ }^{14}$ C B.P. (ca. $10800-10300$ ${ }^{14}$ C B.P.); thus, the Moorhead phase represents a time in landscape evolution when Folsom or younger human populations could have been present. On the north side of the Rainy River, an exposure east of the confluence of the La Vallee River with the Rainy River (Fig. 1) shows the regional sequence (Nielson et al. 1982). Sands of the Moorhead phase overlie clays deposited in an earlier phase of Lake Agassiz. The lake clays are above calcareous 
till. Reddish brown clay with varves overlies the Moorhead sands and represents Emerson phase Lake Agassiz deposits, which continued to about $9500{ }^{14}$ C B.P. (Bajc et al. 2000).

South of the Rainy River, exposures in gravel pits show Rainy lobe till overlain by laminated lake clays and silts. The latter underlie outwash attributed to the St. Louis sublobe or Koochiching lobe. Deposits of glacial Lake Agassiz have been designated as the Little Fork Formation (Ojakangas \& Matsch 1982). The upper terrace on the east side of the Big Fork River contains lacustrine deposits at 329-330.8 masl, buried by alluvium (Birk \& George 1976). After drainage of Lake Agassiz by about $9500{ }^{14}$ C B.P. (Bajc 1991) stream channels were formed on the old lake plain and alluvial deposition began. The initial post-glacial course for the Big Fork River may have followed the lower reaches of the Black River to the west, when the Black River flowed into the Rainy River about $7 \mathrm{~km}$ downstream from the present confluence. A Paleoindian site, the Plummer site (Magner 2001), is situated on a terrace of this earlier combined Big Fork-Black River drainage. The Little Fork River also entered the Rainy River downstream from its present location sometime in the past.

This study examined post-glacial alluvial processes and related landforms in the vicinity of the Hannaford archaeological site. Results indicate three major sets of Holocene terraces are present in the lower reach of the Big Fork River near its confluence with the Rainy River. These terrace surfaces reflect stream responses to Holocene environmental change. The earliest or "upper" terrace (T2) is underlain by Lake Agassiz sediments (Fig. 3). Locally, a treeless tundra-like landscape and spruce parkland existed adjacent to the retreating ice margin and Lake Agassiz. By the time the ice margin was at the Hartman moraine, $130 \mathrm{~km}$ northeast of the Rainy River basin, closed spruce forests had expanded into northwestern Ontario from northern Minnesota (Janssen 1968).

Following the interval of entrenchment that left the early Holocene floodplain as the T2 terrace, the Big Fork River went through an episode of aggradation. This episode was followed by entrenchment that created the T1 terrace, which has numerous paleomeanders on its surface. A prominent scarp separates the T1 terrace from the floodplain complex. Channel scars and ridge-and-swale topography characterize the floodplain surface. The valley fill beneath the floodplain complex had begun to aggrade by $3,000{ }^{14} \mathrm{C}$ B.P.

Changes in the dynamics of Holocene fluvial processes have been related to variations in climate. Middle Holocene dry climates ("Hypsithermal" cf. McAndrews 1982) have been linked to cases of river entrenchment and valley alluviation. For instance, middle Holocene aridity and climate instability has been connected to reduced vegetation and aggradations in the Upper Mississippi Valley (Knox 1972). Middle Holocene aridity led to the eastward and northward expansion of the prairie. East of the Big Fork River at Cayou Lake, Voyageurs National Park, spruce dominated to around $9000{ }^{14} \mathrm{C}$ B.P. and pine became dominant until $6000{ }^{14} \mathrm{C}$ B.P. when climate became its warmest and driest (Davis et al. 2000). It appears that regionally there was a significant change in effective moisture during the middle Holocene, resulting in lower lake levels (Laird \& Cumming 2008). Intensified lateral migration has been attributed to higher flooding frequency and cooler and moister conditions between about 6000 and $4500{ }^{14} \mathrm{C}$ B.P. (Knox 1985). In contrast, higher lateral channel migration and floodplain construction occurred during a period of warmer-drier climate along the Red River with no intensification of fluvial activity after the shift to a cooler-moister climate (Brooks 2003). In other situations where there apparently was a change in forest composition, periodic flooding may be connected with persistent downcutting (Arbogast et al. 2008).

After a period of floodplain deposition there was another major period of incision, this time into the T1 surface. This period of downcutting appears to have occurred prior to 3000 years ago. The downcutting led to the set of surfaces that are associated with the present-day floodplain (grouped together as T0). During this stage, the Big Fork continued to meander, resulting in a series of point bar deposits. Assuming a constant rate of deposition, the radiocarbon date of $1850{ }^{14} \mathrm{C}$ B.P (Table 1, recovered at a depth of $95 \mathrm{~cm}$ for the $1.48 \mathrm{~m}$ core) from the oxbow lake adjacent to the Smith site, implies valley filling began before approximately $3000{ }^{14}$ C B.P.; this is similar to the radiocarbon age of redeposited charcoal in the lower section of Core 2-94 on the west side of the river (Fig. 8). Paleoclimate evidence from the region suggests that climate became cooler and moister after about $5000-3000{ }^{14} \mathrm{C}$ B.P. Myrtle Lake, $70 \mathrm{~km}$ to the southeast, was dominated by pine after 3000 B.P. (Janssen 1968). The shift to wetter climates may have led to a rise in the regional water table, leading to the spread of peat lands and increasing the headward erosion of streams (Glaser et al. 1997). The hydroclimatic record from Hole-in-the-Bog peat land south of the Big Fork drainage shows extreme drought events associated with fluctuations during the Medieval Warm Period or Climatic Anomaly (Laird et al. 1996, Booth et al. 2006). 
Isostatic depression by the Laurentide Ice Sheet has resulted in post-glacial rebound. This is demonstrated by the differential tilting of Lake Agassiz shorelines. How has the rate of uplift affected the Big Fork stream gradient? Was it initially very fast, leading to incision? Did later slower rebound contribute to floodplain stability? The gradients and base levels of river systems affected by differential uplift in areas deglaciated during the late Quaternary include river incision and terrace formation as well as valley aggradation (Brooks et al. 2005). Differential uplift on the Big Fork might mirror the Red River to the west where a 60 percent loss of gradient has occurred in the last 8000 years. The Lower Campbell beach shows that from the southern outlet of Agassiz to Lake Winnipeg there has been uplift of $64 \mathrm{~m}$. Long term changes in fluvial processes associated with uplift may be important to archaeological site locations (settlement patterns) along low-gradient rivers (Brooks et al. 2005). In the Big Fork drainage, based on the difference between isobase 5 and 6 (Teller 2001), vertical displacement by uplift-rebound may be on the order of approximately $40 \mathrm{~m}$ since the formation of the Upper Campbell beach around $9500{ }^{14} \mathrm{C}$ B.P.

The distribution of artifacts appears to reflect changing human use of parts of the late Holocene floodplain and site microenvironment. The earliest documented human presence at the Hannaford site is associated with Early Blackduck artifacts starting at approximately $1300{ }^{14} \mathrm{C}$ B.P., found on the west side of the Hannaford site. These artifacts are confined to Area A, which at the time was adjacent to the Big Fork River; the sediments presently east of Area A had not yet been deposited because that part of the floodplain was probably the location of the river (Figs. 8-9). Some possible Early Blackduck artifacts have been recorded in the eastern part of the site in deeply buried but artifact-poor deposits along the current river bank; these could be the result of secondary deposition resulting from fluvial activity.

By approximately $1050{ }^{14} \mathrm{C}$ B.P. Middle Blackduck artifacts are present at the site. The most extensive Middle Blackduck presence was also in Area A, but some river bank areas to the east may have also been used. It is possible to divide the Middle Blackduck assemblages into two temporal groups. The first would be the extensive use of Area A and minimal use of the river bank. The second interval involves a shift in emphasis from Area A to Area D, closer to the present-day river; during this time Area A appears to have received less use than the river bank. Most Middle Blackduck zones along the river are separated from the Late Blackduck artifact zone by sediments without artifacts. Late Blackduck (= Rainy River Late Woodland Complex) artifacts are found along the river bank at approximately $900{ }^{14} \mathrm{C}$ B.P. The most recent dated Lake Blackduck phase artifacts occur in Area D at approximately $650{ }^{14} \mathrm{C}$ B.P.

The sedimentary sequence at Hannaford records a bipartite pattern of lateral channel accretion and vertical overbank accretion over the past 3000 or more years. This pattern produced a changing microenvironmental landscape context that in turn influenced site selection, intensity of use, and affected the distribution and preservation of archaeological occurrences. On the basis of sedimentary stratigraphy, artifact assemblages, and radiocarbon dates, a four-stage model can be proposed showing the interrelationships between sedimentation and human activity that reflect the processes of site formation (Fig. 9).

Before about $1500{ }^{14} \mathrm{C}$ B.P., prior to the onset of the Medieval Climate Anomaly, the locus of the Hannaford site was still within the channel of the Big Fork River (Fig. 9, stage I). The river was migrating eastward and southward by means of lateral channel movement, i.e., concave bank erosion and convex bank (point bar) deposition. Along the river, the convex banks form the locations of deposition on gently sloping accretionary landforms (point bars). The Hannaford site was located on the northernmost point bar on the east side of the Big Fork River. Because of lateral accretion, the point bar was gradually increasing in height and migrating toward the northeast. Lateral accretion resulted in the deposition of relatively coarse sediments including sandy gravel, and coarse to fine sand showing a fining-upward sequence. The relatively coarse-grained sediments constitute the "bottom series" of the stratigraphic sequence. As the point bar deposition continued, the subaqueous point bar surface emerged gradually from southwest to northeast. The topography of the emerging point bar consisted of a series of roughly concentric ridges and swales.

Around $1400{ }^{14} \mathrm{C}$ B.P. the point bar surface in the west side of the Hannaford site (Area A) was emerging from the channel due to lateral accretion. Human use began to take place on the west part of the site around $1400{ }^{14} \mathrm{C}$ B.P. after the sedimentary environment had gradually shifted from primarily lateral to vertical accretion. After subaerial emergence, the point bar remained relatively stable and started receiving vertical accretion sediments created by intermittent overbank flooding. The floodplain would have been dry most of the year and intermittently inundated during relatively brief periods of overbank flooding. The site would have been occupied during the period of normal stream flow; however, human activity was not feasible when the floodplain was inundated by floodwaters. 
While the vertical accretion deposits were accumulating upward, the point bar continued to migrate gradually to the east by deposition in the channel bed. By about $1300{ }^{14} \mathrm{C}$ B.P. (Fig. 9, stage II), the channel had migrated to the east of Area B. Early Blackduck artifacts from Areas A and B are associated with an organic rich zone consisting of a series of thin layers in the lower part of "top series" deposits. Sometime after $1100{ }^{14}$ C B.P., roughly corresponding to the beginning of the Medieval Climatic Anomaly (Mann et al. 2009), a relatively large flooding event covered the site with a thin $(3-4 \mathrm{~cm})$ bed of fine sand, designated stratum 5 in Area A (Fig. 6).

Like other meandering rivers, the Big Fork River inundated the floodplain periodically. Sediments suspended in the floodwaters accumulated on the upper portion of the point bar. Early Blackduck artifacts in the lower strata in Areas C, D, and E are believed to be in secondary context. This inference is supported by stratigraphic position, sedimentary context, and inverted radiocarbon dates. The Early Blackduck artifacts are embedded in the "bottom series" sediments that were created by point bar deposition on the channel bed. Some pottery fragments found at the depth of $1.98 \mathrm{~m}$ in Core 5-92 could be in a similar situation. These redeposited artifacts might be derived from the early phase of human presence in Areas A and B during the Early Blackduck period when the river channel bank close to Area B and Area D was within the river channel. The Early Blackduck artifacts at 85-100 cm in Area C are probably also in secondary context.

As the coarse sediments continued to accumulate on the channel bed by point bar deposition, the bank of the river moved to its current position (east of Areas D and C), probably around $900{ }^{14}$ C B.P. (Fig. 9, stage III). The water table was probably lower during this time as a result of decreasing stream discharge. The point bar became stabilized due to the development of a younger point bar system south of the site. Vertical accretion deposits began to accumulate on the stabilized point bar platform. As a result, a natural levee started to form and a relatively thick sequence of vertical accretion sediments was deposited. The newly formed bank became a location for human activity. Meantime, the previous locations of occupation were still utilized during normal stream flow periods. In addition to the normal-magnitude overbank flooding, relatively major flooding occurred occasionally; at least two large magnitude floods occurred. The flooding deposited a thin layer or lens of fine sand over the occupied area near the channel. Continued use of the river bank areas is reflected by the presence of younger artifacts. The youngest dated Blackduck artifacts (Rainy River Late Woodland Complex) are in Area D at approximately $650{ }^{14}$ C B.P.

The vertical accretion deposits are the locations of primary archaeological records at the Hannaford site. As a result of flooding, artifacts and features associated with the human activities on the floodplain surface were buried as finegrained sediments settled from suspension during the waning stages of stream flow. After flooding, the site was used again. Sometimes the site was covered with a relatively thick layer of sediments produced by individual major flooding. Thus, the new activity surface could be separated by a layer of sediment from the set of older artifacts. As a result of repeated intermittent periods of landscape stability and human use of the floodplain from the about 1500 to $600{ }^{14} \mathrm{C}$ B.P.

stratified layers containing artifacts were incorporated within the "top series" sediments. The site is still subject to the episodic deposition of overbank flooding (Fig. 9, stage IV).

The four-stage model of site formation presents a picture of how sedimentary environments and associated deposits dynamically affected the distribution and preservation of artifact assemblages on the floodplain of the Big Fork River. The alluvial model has implications for interpreting the archaeological records at other sites with similar geologic settings. In a meandering point bar setting, artifacts in primary contexts are normally found in association with vertical accretion sediments instead of lateral accretion sediments of the floodplain. Artifacts could be incorporated into lateral accretion deposits, but usually only in secondary contexts. Erosion of archaeological can occur along stream banks of the river. Dashed lines in Fig. 9 show our estimate of the land surface at a particular time and what we interpret as the position of the river edge.

\section{Conclusions}

This study provides a reconstruction of environmental events along the lower Big Fork River, relates the sedimentological processes to the archaeological record, and examines human activities related to a dynamic riparian environment and its resources. By the time that people were using Clovis artifacts, around $11000{ }^{14}$ C B.P., glaciers had melted north of the study area to the Rainy River moraine. At the time human groups were using Folsom artifacts, around $10800-10300{ }^{14}$ C B.P., the Big Fork area was available for human habitation due to the 
Moorhead low stage of Lake Agassiz. The geomorphic and stratigraphic records reflect the fluvial dynamics of the Big Fork River once it became established on the lake sediments of glacial Lake Agassiz after approximately 9500 ${ }^{14}$ C B.P. The river has since eroded a valley that contains a floodplain complex and two terraces near its confluence with the Rainy River. The valley fill beneath the oldest and highest terrace (T2) contains Archaic artifacts and overlies lacustrine deposits of glacial Lake Agassiz. The T1 fill represents an aggrading floodplain; this terrace surface consists of distinct meanders. The youngest valley fill underlies the floodplain complex; aggradation is estimated to date to at least $3000{ }^{14} \mathrm{C}$ B.P. The curvilinear pattern of ridge-and-swale swale topography across $\mathrm{T} 1$ and T0 indicates that these floodplains are the result of lateral migration of the stream channel. After a period of middle Holocene entrenchment and drier climates, the lower terrace appears to be linked to overall wetter climate conditions punctuated by intervals of drought. This latest phase of aggradation appears to have lasted several thousand years during which the dynamics of the river have been influenced by more modest fluctuations in climate.

The Hannaford site is a late Holocene, multi-component, stratified locality situated on the west bank of the lower Big Fork River in northern Minnesota. Its geologic setting in the active floodplain of a meandering river produced a series of discrete sedimentary strata that comprise two general groups. The lower, coarse-grained strata ("bottom series") are primarily the result of point bar deposition when the river was farther west of its present position. The upper, finer-grained sediments ("top series") represent deposition from various overbank flooding events. This boundary is time-transgressive; it developed as the river channel migrated east, and so it is older in the west.

Contained within these strata are Late Woodland artifacts that were used by prehistoric hunter-gatherers. Most of the artifacts are located within the upper sediments and are in primary context, although affected to some degree by the flooding events that buried them. Artifacts within point bar deposits are more likely to be secondary deposits. Radiocarbon dates from the floodplain imply aggradational processes have dominated at least since $3000{ }^{14} \mathrm{C}$ B.P. The alluvial geomorphic setting provided a microenvironmental context associated with fishing and aquatic mammals. There appears to have been a shift in the types of fish over time; there is a change from the procurement of lake sturgeon by spearing (as represented on the west side of the site in Area A) to taking bottom-feeding fish like redhorse (on the east side of the site at Area D). These fishing stations may have been seasonal to take advantage of the spring fishing runs. A more permanent human presence would have been difficult in a riparian setting characterized by flooding.

The radiocarbon dates indicate that some reworking (erosion and redeposition) of artifacts has occurred. The crosssections show a series of aggrading river deposits. Based on these cross-sections we propose that there was a progressive expansion of land toward the east and north associated with the human prehistoric presence at Hannaford from about $1300-650{ }^{14} \mathrm{C}$ B.P. Regionally, extreme drought events at 1000, 800, and 700 B.P. within this time period of human presence are associated with climate fluctuations during the Medieval Warm Period. The transition from the early part of the sequence characterized by Early and Middle Blackduck artifacts to the late part of the sequence containing Rainy River Late Woodland Complex artifact assemblages along the Big Fork River roughly coincides with the beginning of the Medieval Climatic Anomaly at $1100-1050{ }^{14} \mathrm{C} \mathrm{B.P}$. The youngest part of the archaeological sequence dates to before the onset of the Little Ice Age.

This research was conducted partially under Minnesota Department of Transportation Agreement 70974, G.J. Hudak project manager. Laboratory analyses for the project were conducted by personnel at the University of Minnesota's Archaeometry Laboratory with contributions by S.C. Mulholland, S.L. Mulholland, D.E. Stoessel, S.H. Valppu, J.K. Huber, and C. Elmgren. Thanks to Cheryl L. Hill for the production of the final versions of the maps and stratigraphic profiles. C. Kubeczko also provided help. We thank two anonymous reviewers for the excellent suggestions that improved the manuscript. 


\section{References}

Arbogast, A., Bookout, J., Schrotenboer, B., Landsdale, A., Rust, G., \& Bato, V. 2008. Post-glacial fluvial response and landform development in the upper Muskegon River valley in North-Central Michigan, U.S.A. Geomorphology 102, 615-623.

Arzigian, C. 2008. Minnesota Statewide Multiple Property Documentation Form for the Woodland Tradition. Mississippi Valley Archaeological Center Report No. 735, University of Wisconsin, La Crosse.

Bajc, A. 1991. Glacial and glaciolacustrine history of the Fort Frances-Rainy River area, Ontario, Canada. University of Waterloo.

Bajc, A., Schwert, D., Warner, B., \& Williams, N. 2000. A reconstruction of Moorhead and Emerson Phase environments along the eastern margin of glacial Lake Agassiz, Rainy River basin, northwestern Ontario. Canadian Journal of Earth Sciences 37, 1335-1353.

Benito, G., Baker, V., \& Gregory, K. (eds) 1998. Palaeohydrology and Environmental Change. Wiley, Chichester.

Birk, D., \& George, D. 1976. A Woodland Survey Strategy and its Application to a Late Archaic Locus of the Smith site (21KC3), Koochiching County, Minnesota. The Minnesota Archaeologist 35, 1-30.

Booth, R., Notaro, M., Jackson, S., \& Kutbach, J. 2006. Widespread drought episodes in the western Great Lakes region during the past 20000 years: geographic extent and potential mechanisms. Earth and Planetary Science Letters 242, 415-427.

Bridgland, D. \& Westway, R. 2008. Climatically controlled river terrace staircase: A worldwide Quaternary phenomenon. Geomorphology 98, 285-315.

Brooks, G. 2003. Holocene lateral channel migration and incision of the Red River, Manitoba, Canada. Geomorphology 54, 197-215.

Brooks, G., Thorleifson, L., \& Lewis, C. 2005. Influence of loss of gradient from postglacial uplift on Red River flood hazard, Manitoba, Canada. The Holocene 15, 347-352.

Bull, W. 1991. Geomorphic Responses to Climatic Change. Oxford University Press, New York.

Butzer 1982

Davis, M., Douglas, C., Calcote, R., Cole, K., Winkler, M., \& Flake, R. 2000. Holocene climate in the Western Great Lakes National Parks and Lakeshores: Implications for Future Climate Change. Conservation Biology 14, 968-983.

Fisher, T., Yansa, C., Lowell, T., Lepper, K., Hajdas, I., \& Ashworth, A. 2008. The chronology, climate, and confusion of the Moorhead Phase of glacial Lake Agassiz: new results from the Ojata Beach, North Dakota, U.S.A. Quaternary Science Reviews 27, 1124-1135.

Glaser, P., Siegel, D., Romanowicz, E., \& Shen, Y. 1997. Regional linkages between raised bogs and the climate, groundwater, and landscape of northwestern Minnesota. Journal of Ecology 85, 3-16.

Gregory, K., \& Benito, G. (eds), 2003. Palaeohydrology: Understanding Global Change. Wiley, Chichester.

Hill, C. 2007. Geoarchaeology and Late Glacial landscapes in the western Lake Superior region, central North America. Geoarchaeology 22, 15-47. 
Hill, C., Rapp, G., Valppu, S., \& Jing, Z. 1995. Geoarchaeology and geochronology of the Hannaford site.

Archaeometry Laboratory Report Number 95-7, Technical Report to the Minnesota Department of Transportation.

Janssen, C. 1968. Myrtle Lake: a late-and post-glacial pollen diagram from northern Minnesota. Canadian Journal of Botany 46, 1397-1408.

Knox, J. 1972. Valley alluviation in southwestern Wisconsin. Annals of the Association of American Geographers 62, 401-410.

Knox, J. 1983. Responses of river systems to Holocene climates. Late Quaternary Environments of the United States, v. 2, H.E. Wright, (ed). University of Minnesota Press, Minneapolis, 26-41.

Knox, J. 1985. Responses of floods to Holocene climatic change in the Upper Mississippi Valley. Quaternary Research 23, 287-300.

Knox, J. 1993. Large increases in flood magnitude in response to modest changes in climate. Nature 361, 430-432.

Laird, K., Fritz, S., Maasch, K., \& Cumming, B. 1996 Greater drought intensity and frequency before A.D. 1200 in the northern Great Plains, U.S.A. Nature 384, 552-554.

Laird, K., \& Cumming, B. 2008. Reconstruction of Holocene lake level from diatoms, chryosophytes and organic matter in a drainage lake from the Experimental Lakes Area (northwestern Ontario, Canada). Quaternary Research 69, 292-305.

Lenius, B., \& Olinyk, D 1990. The Rainy River Composite: Revisions to Late Woodland taxonomy. The Woodland Tradition in the Western Great Lakes. G. Gibbon (ed.). Publications in Anthropology No. 4, University of Minnesota, Minneapolis, 77-112

Lowell, T., Fisher, T., Hajdas, I., Glover, K., Loope, H., \& Henry, T. 2009 Radiocarbon deglaciation chronology of the Thunder Bay, Ontario, area and implications for ice retreat patterns. Quaternary Science Reviews 28:15971607.

Mandel, R., Bettis, E. 2001 Use and analysis of soils by archaeologists and geoscientists: A North American perspective. Earth Sciences and Archaeology, P. Golberg, V. Holliday, C. Ferring, (eds.). Kluwer/Plenum, New York, 173-204.

Mann, M., Zhang, Z., Rutherford, S., Bradley, S., Hughes, M., Shindell, D., Ammann, C., Faluvegi, G., \& Ni., F. Global signatures and dynamical origins of the Little Ice Age and Medieval Climatic Anomaly. Science 326: 12561260 .

Magner, M. 2001. The Lake of the Woods/Rainy River Late Paleoindian Complex: an initial assessment from the Rainy River Region in Minnesota. Minnesota Archaeologist 60: 87-98.

McAndrews, J. 1982. Holocene environment of a fossil bison from Kenora, Ontario. Ontario Archaeology 37: 4151.

Nielsen, E. McKillop, W., \& McCoy, J. 1982. The age of the Hartman moraine and the Campbell beach of Lake Agassiz in northwestern Ontario. Canadian Journal of Earth Sciences 19, 1933-1937.

Ojakangas, R., \& Matsch, C. 1982. Minnesota’s Geology. University of Minnesota Press, Minneapolis. 
Rapp, G., Mulholland, S.C., Mulholland, S., Jing, Z,. et al. 1995. Final Report: Hannaford Data Recovery Project, Koochiching County, Minnesota. Archaeometry Laboratory Report Number 95-31, University of Minnesota, Duluth.

Schumm, S., Brakenridge, R. 1987. River responses. North America and Adjacent Oceans during the Last Deglaciation. The Geology of North America, v k-3. Geological Society of America, Boulder, CO., 221-240.

Teller, J. 2001. Formation of large beaches in an area of rapid differential isostatic rebound: the three-outlet control of Lake Agassiz. Quaternary Science Reviews 20, 1649-1659.

\section{Figure Captions}

1. Regional map.

2. Geomorphic setting.

3. Cross-section A-B across the Big Fork River.

4. Paleogeographic reconstruction of the Hannaford site on the late Holocene terrace.

5. Area A Stratigraphic Section.

6. Area D Stratigraphic Profile.

7. Cross-section C-D.

8. Cross-section E-F.

9. Four-stage model of landscape evolution.

Table

\begin{tabular}{|c|c|c|c|c|}
\hline \multicolumn{5}{|c|}{ Hannaford Table 1. Radiocarbon Measurements } \\
\hline $\begin{array}{l}\text { Radiocarbon } \\
\text { Age }\end{array}$ & $\begin{array}{l}\text { 1-Sigma } \\
\text { Standard } \\
\text { Deviation }\end{array}$ & $\begin{array}{l}\text { Laboratory } \\
\text { Number }\end{array}$ & Material & $\begin{array}{l}\text { Sample I.D. and Stratigraphic } \\
\text { Context }\end{array}$ \\
\hline 1240 & 60 & Beta-61879 & charcoal & $\begin{array}{l}\text { 30-1, Area A, stratum 2, Blackduck } \\
\text { artifacts }\end{array}$ \\
\hline 1460 & 80 & Beta 54638 & charcoal & $\begin{array}{l}28-1 \text {, Area A, stratum } 3 \text { (below Blackduck } \\
\text { artifacts) }\end{array}$ \\
\hline 1470 & 60 & Beta-61890 & carbon crust & 92-1, Area A, stratum 4, not used \\
\hline 1330 & 70 & Beta-61891 & charcoal & 93-1, Area A, stratum 4, Early Blackduck \\
\hline 980 & 70 & Beta-61888 & charcoal & $\begin{array}{l}\text { 84-1, Area A, stratum 6a, Blackduck } \\
\text { hearth }\end{array}$ \\
\hline 1330 & 80 & Beta-54637 & charcoal & 12-1, Area A, Early Blackduck \\
\hline 1650 & 60 & Beta-61878 & carbon crust & 12-2, Area A, Early Blackduck \\
\hline 1160 & 80 & Beta-54639 & charcoal & 41-1, Area B, 45-40 cm, Blackduck hearth \\
\hline 1350 & 50 & Beta-74334 & charcoal & 80-31, Area B, 42-37 cm, top series \\
\hline 930 & 60 & Beta-61874 & charcoal & $2-1$, Area C, top series \\
\hline 1460 & 60 & Beta-61886 & carbon crust & 53-1, Area D, stratum 23, not used \\
\hline 1240 & 60 & Beta-61887 & carbon crust & 53-2, Area D, stratum 22, not used \\
\hline 670 & 90 & Beta-61889 & charcoal & $88-1$, Area D, stratum 20 (late Blackduck) \\
\hline
\end{tabular}




\begin{tabular}{|c|c|c|c|c|}
\hline 720 & 80 & Beta-61881 & charcoal & 47-1, Area D, stratum 20 (late Blackduck) \\
\hline 1280 & 60 & Beta-61882 & carbon crust & 47-2, Area D, stratum 19, not used \\
\hline 1020 & 60 & Beta-61875 & charcoal & $\begin{array}{l}\text { 5--1, Area D, stratum } 16 \text { (Middle } \\
\text { Blackduck) }\end{array}$ \\
\hline 1090 & 70 & Beta-61880 & charcoal & $\begin{array}{l}\text { 46-1, Area D, stratum } 16 \text { (Middle } \\
\text { Blackduck) }\end{array}$ \\
\hline 1160 & 70 & Beta-61883 & charcoal & $\begin{array}{l}\text { 50-1, Area D, stratum } 13 \text { (Middle } \\
\text { Blackduck) }\end{array}$ \\
\hline 1150 & 60 & Beta-61884 & charcoal & 51-1, Area D, stratum 4 (Early Blackduck) \\
\hline 1020 & 60 & Beta-61885 & charcoal & 51-2, Area D, strata 1/2 (Early Blackduck) \\
\hline 1420 & 60 & Beta-61876 & charcoal & 10-1, Area E, Late Blackduck (zone 1a) \\
\hline 1310 & 60 & Beta-61877 & carbon crust & 10-2, Area E, Early Blackduck, zone 3) \\
\hline 1290 & 60 & Beta-61872 & charcoal & Core 3-92, top series \\
\hline 1360 & 60 & Beta-61873 & wood & Core 5-92, 300-275 cm, slackwater facies \\
\hline 2130 & 60 & Beta-78699 & charcoal & $\begin{array}{l}\text { Core 9-92, west of Area A, } 100.5 \mathrm{~cm} \text {, } \\
\text { bottom series }\end{array}$ \\
\hline 1340 & 50 & Beta-78701 & charcoal & $\begin{array}{l}\text { Core 11-92, southeast of Area B, } 63 \mathrm{~cm} \text {, } \\
\text { bottom series }\end{array}$ \\
\hline 1750 & 40 & Beta-78702 & charcoal & $\begin{array}{l}\text { Core } 11-92 \text {, southeast of Area B, } 151.5 \\
\mathrm{~cm} \text {, bottom series }\end{array}$ \\
\hline 1470 & 60 & Beta-77958 & charcoal & $\begin{array}{l}\text { Core 1-94, northwest of Area D, } 200 \mathrm{~cm} \text {, } \\
\text { bottom series }\end{array}$ \\
\hline 5400 & 60 & Beta-77959 & charcoal & $\begin{array}{l}\text { Core } 2-94,80 \mathrm{~cm} \text {, bottom series } \\
\text { (redeposited) }\end{array}$ \\
\hline 2140 & 40 & Beta-77960 & charcoal & Core 2-94, $238-236 \mathrm{~cm}$, bottom series \\
\hline 2980 & 50 & Beta-77961 & charcoal & $\begin{array}{l}\text { Core 2-94, 250-248 cm, bottom series } \\
\text { (redeposited) }\end{array}$ \\
\hline 2290 & 60 & Beta-77962 & charcoal & Core $2-94,268-266 \mathrm{~cm}$, bottom series \\
\hline 1830 & 50 & Beta-78697 & charcoal & Core from Oxbow Lake, 95-94 cm \\
\hline
\end{tabular}




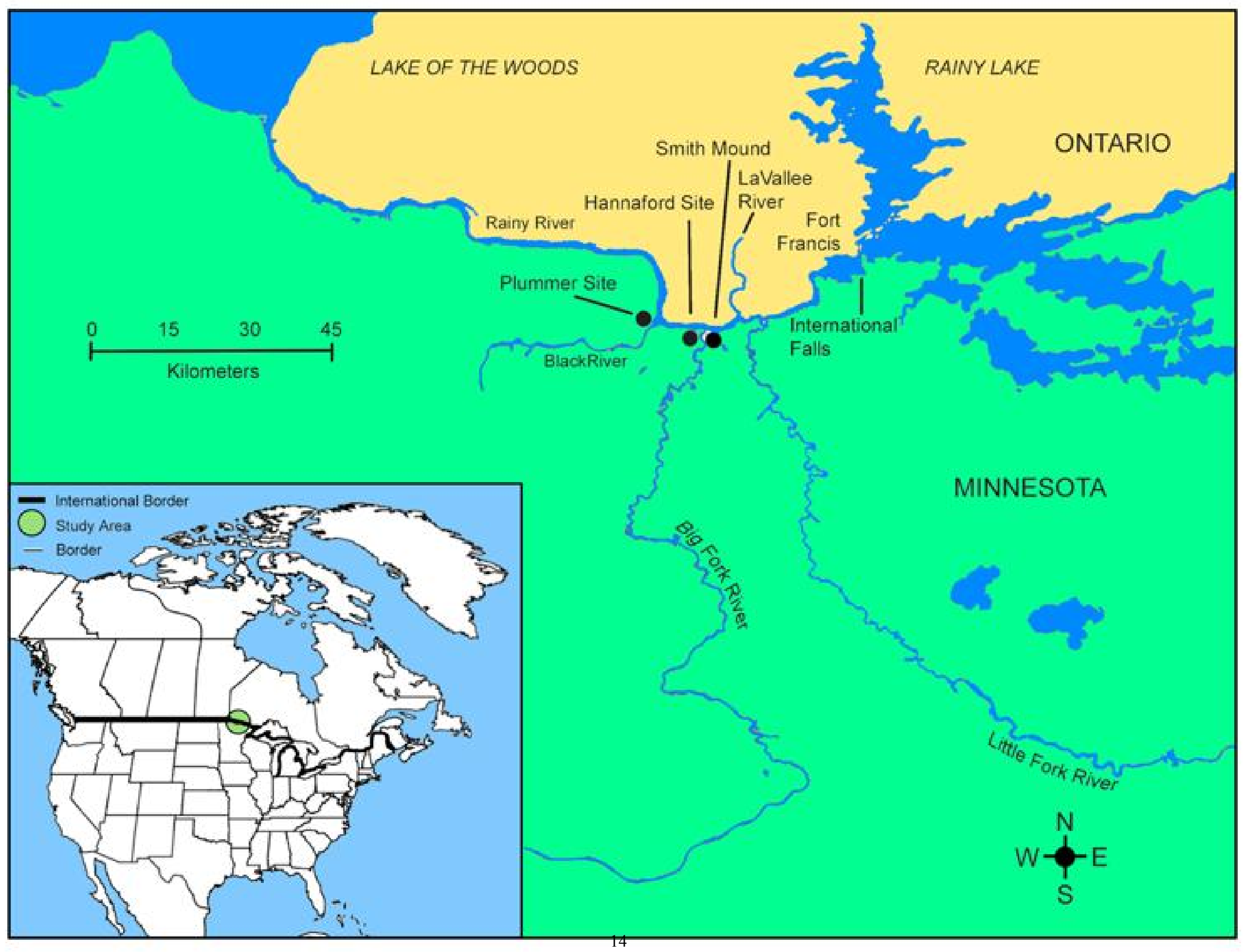




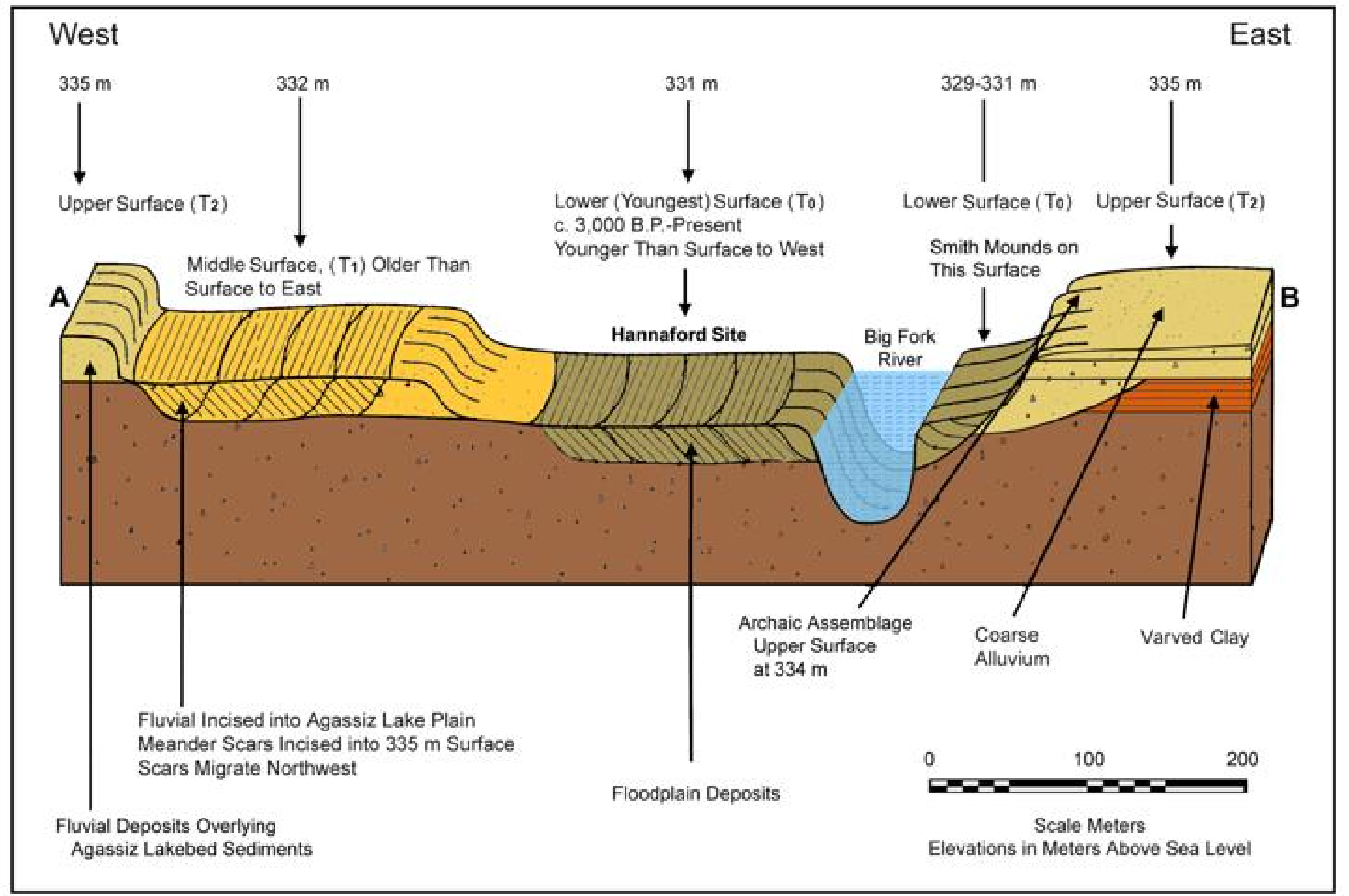




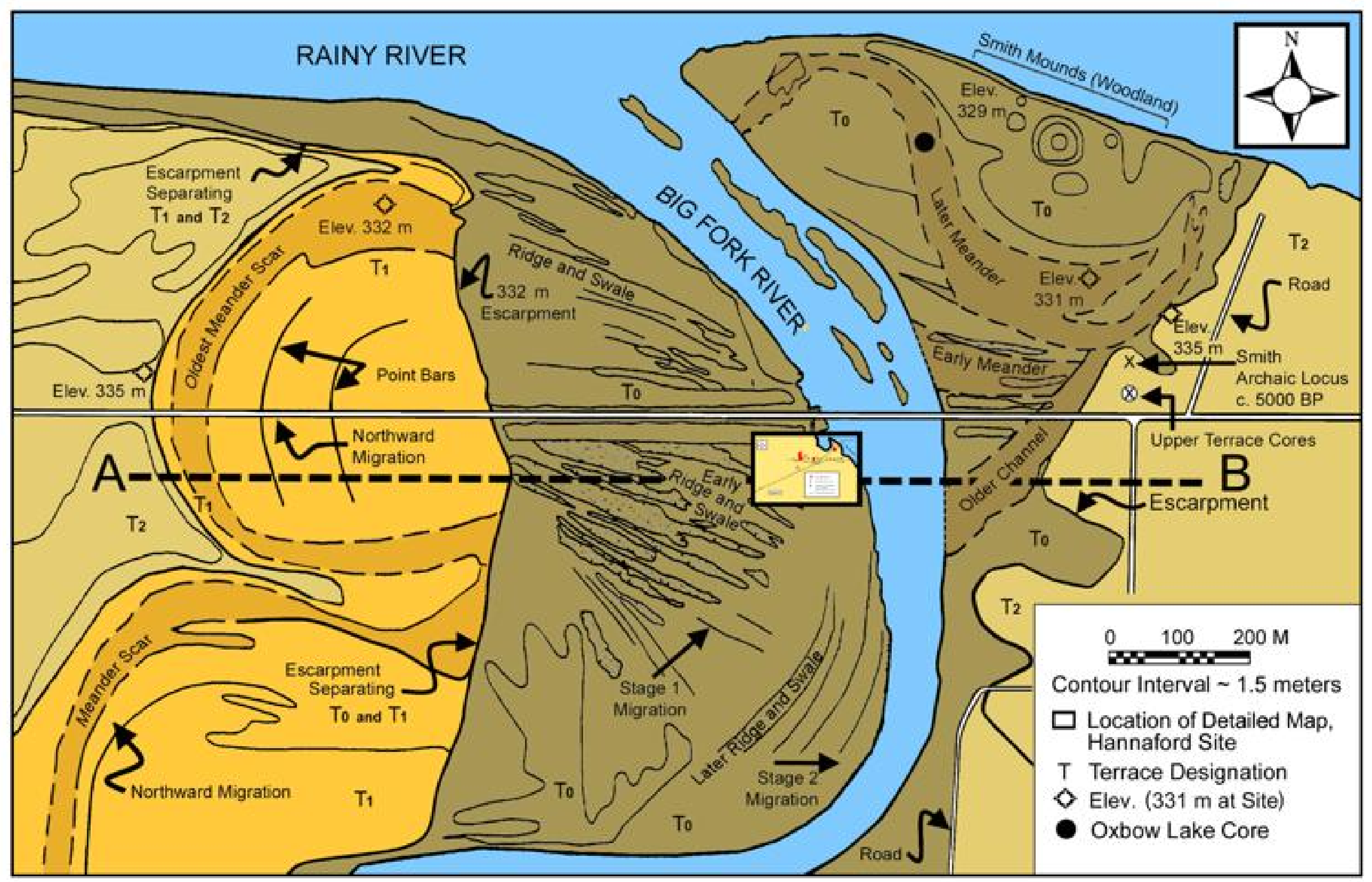




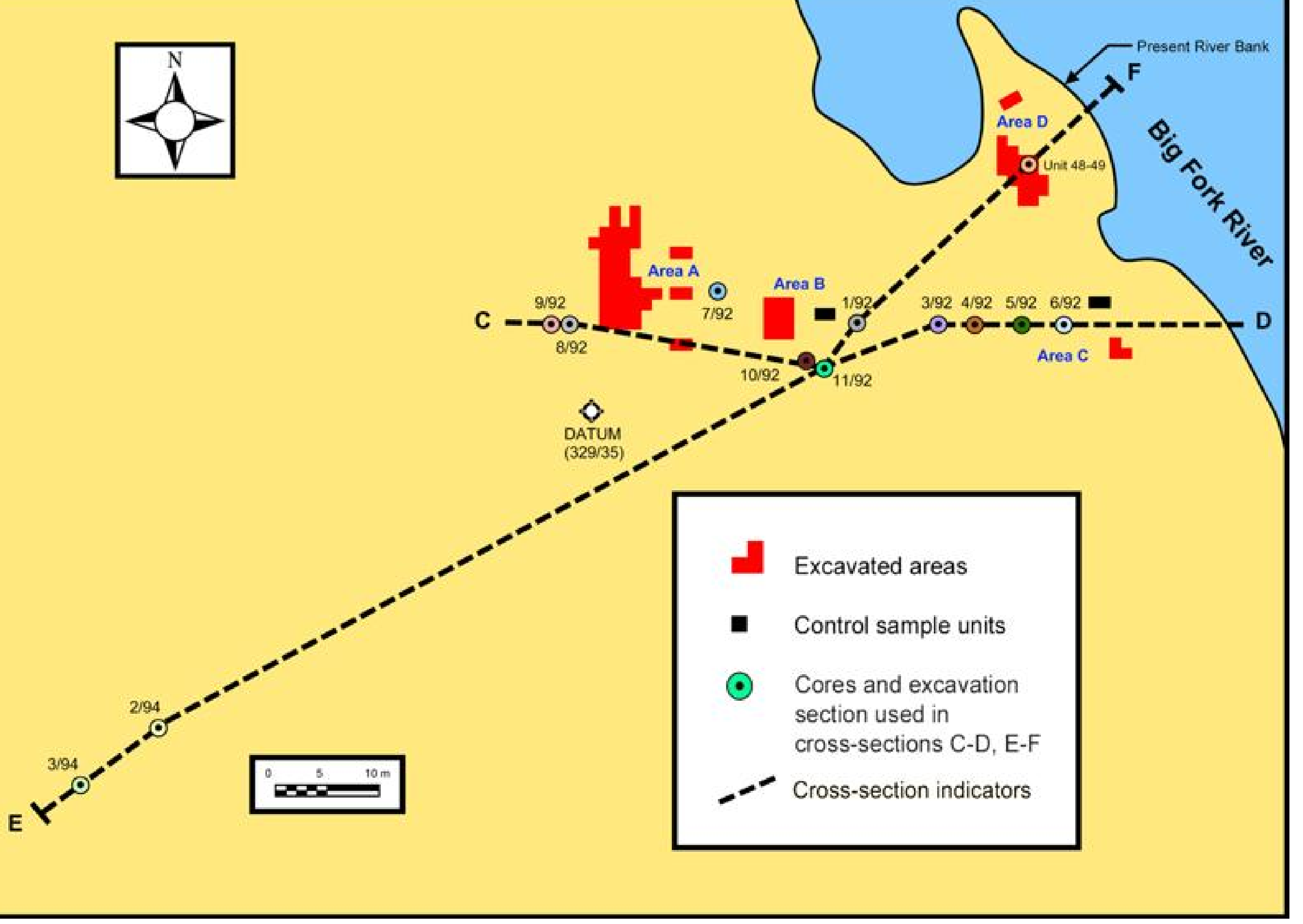




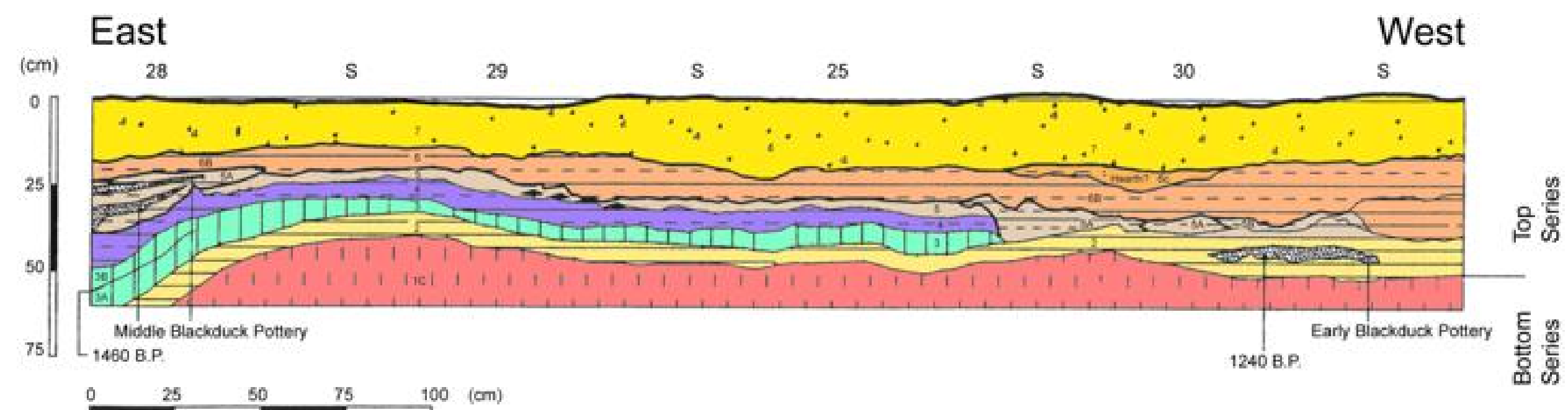

South

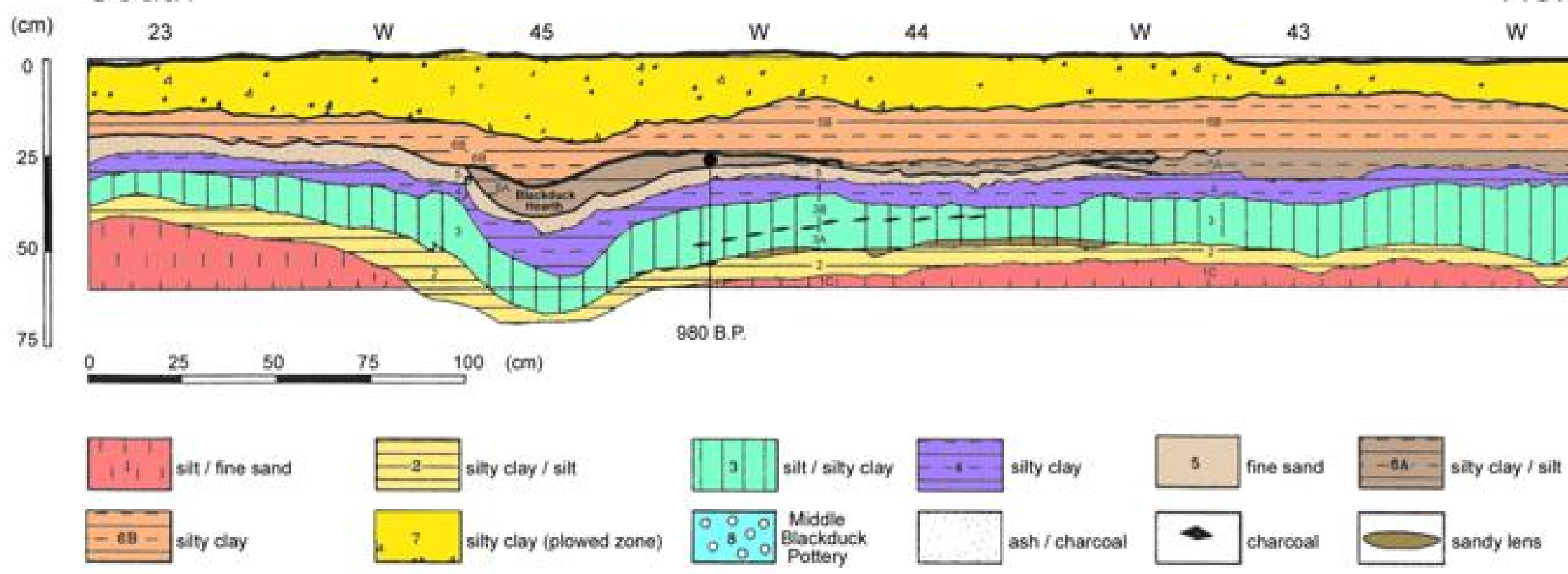

Figure 5 Area A Stratigraphic Section 


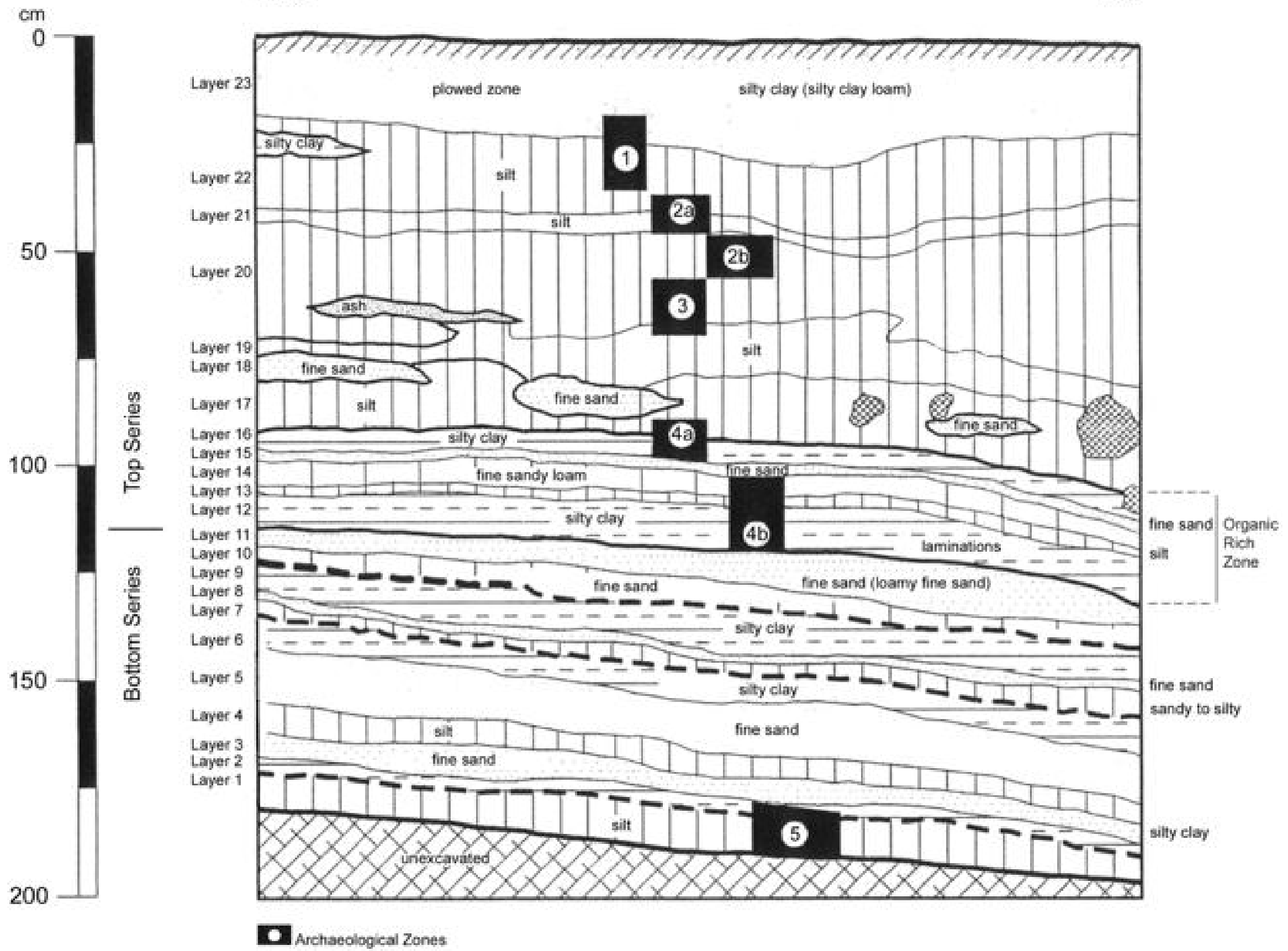

Figure 6 Area D Stratigraphic Profile 
C

West
D

East

\section{Hannaford Site}

\begin{tabular}{lll}
\hline Area A & Area B & Area C \\
\hline
\end{tabular}
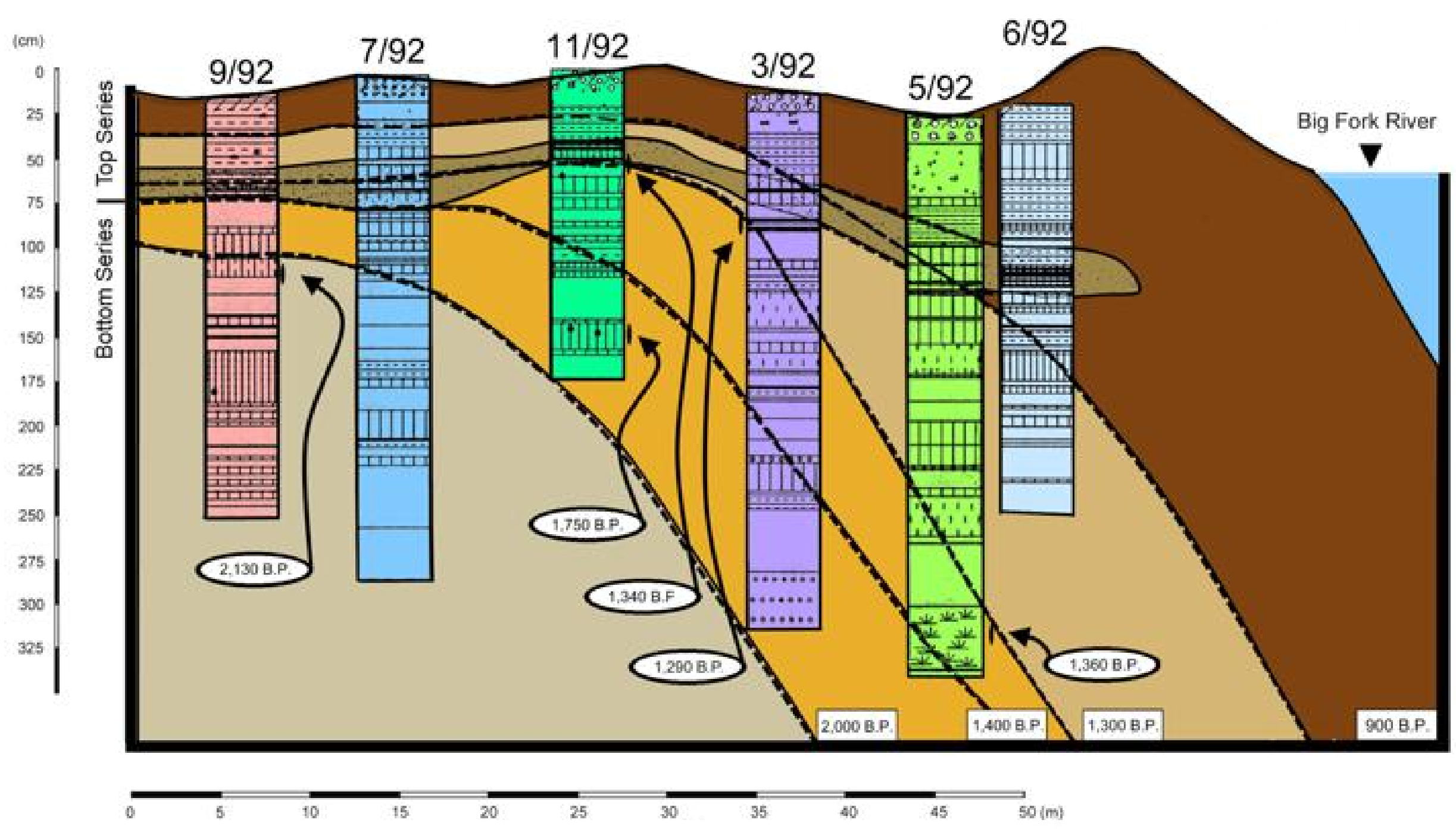
Southwest

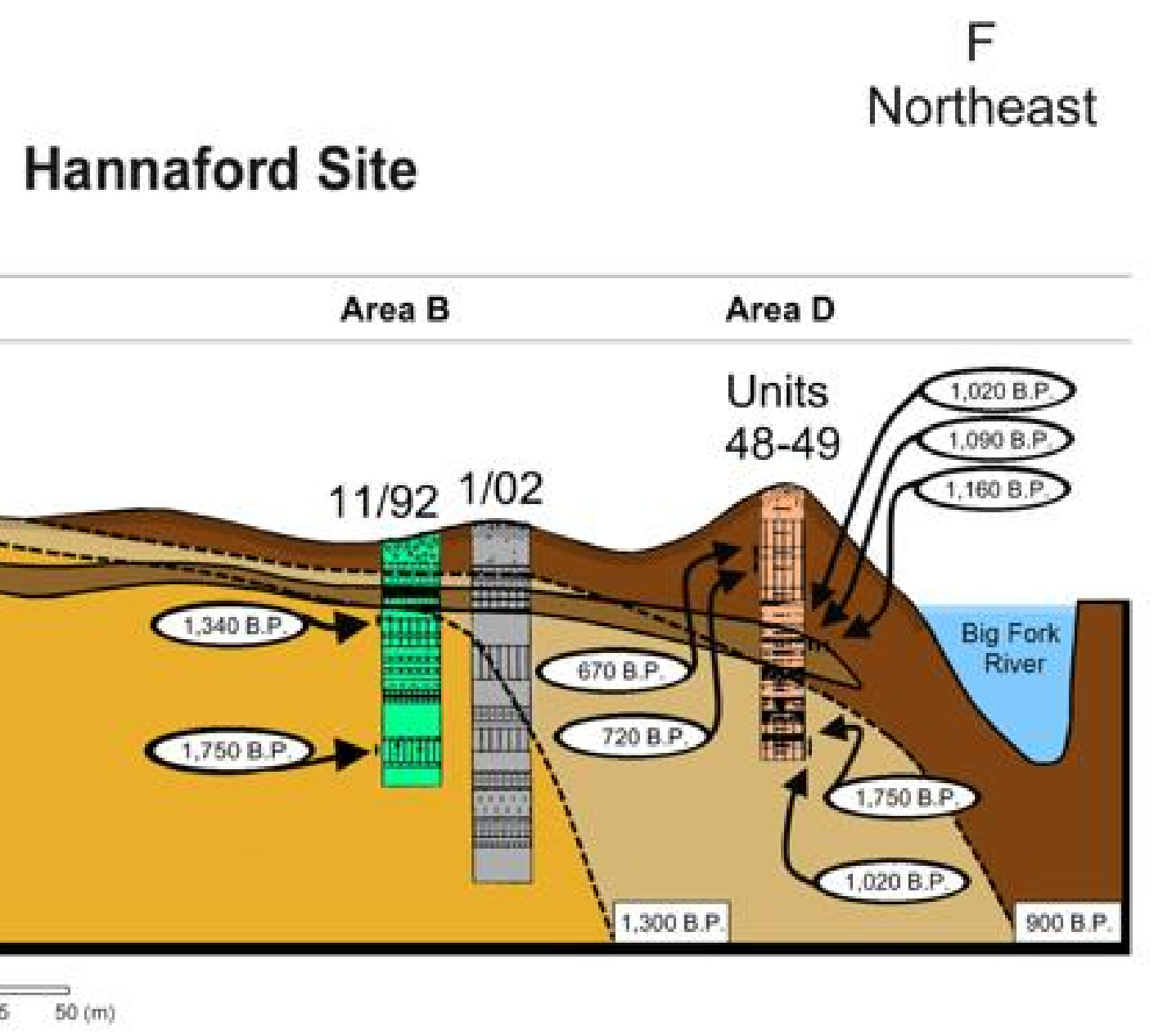




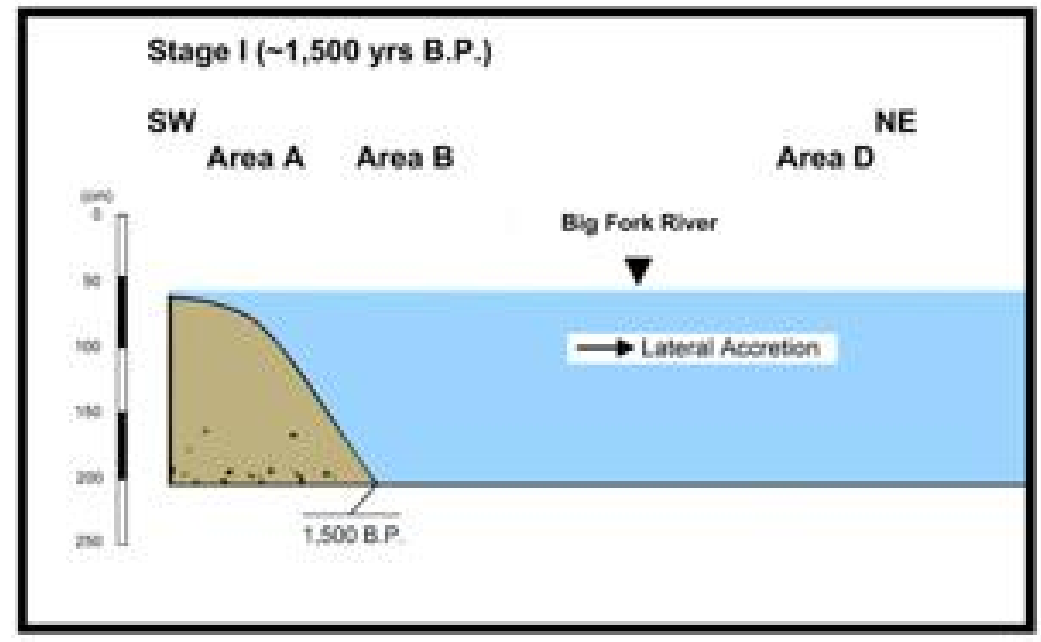

Stage II ( 1,300 yrs B.P.)

SW

Area A Area B

NE

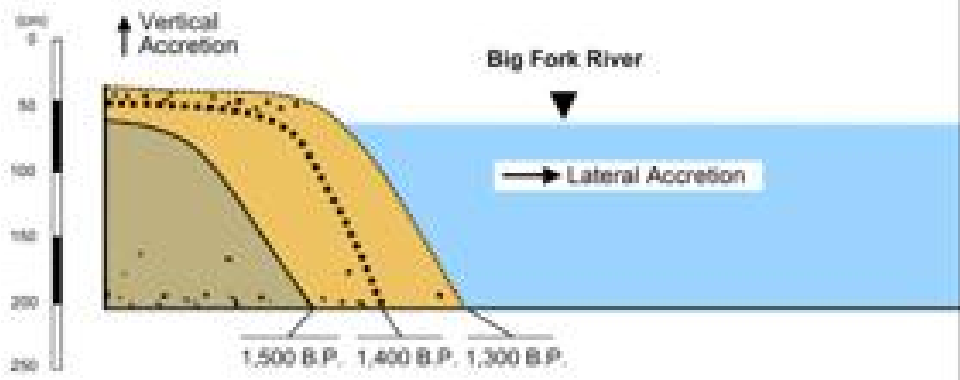

Stage III ( -900 yrs B.P.)

sw

Area A Area B

Area D

NE

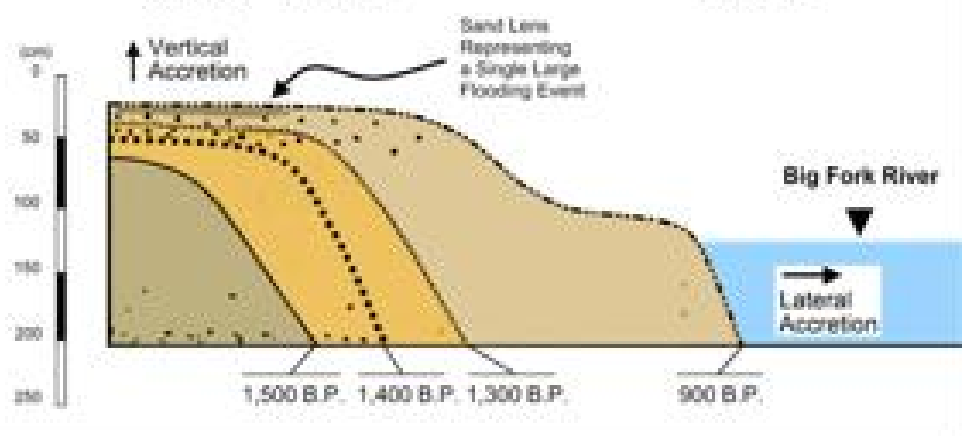

Stage IV (-Modern)

SW Area A Area B Area D

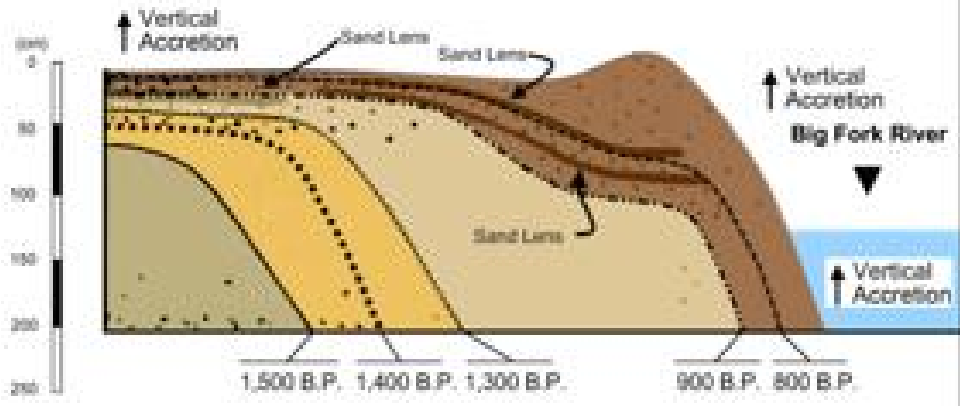

